\title{
SEMENTES COM OPÉRCULO
}

\section{WALTER RADAMES ACCORSI}

Prof. Cat. de Botânica Geral e Descritiva da E. S. A.

"Luiz de Queiroz", da Universidade de S. Paulo

\section{NOTA PRELIMINAR}

Após concluir o estudo sôbre a ocorrência de um órgão cupuliforme, com pêlos absorventes nos bordos e situado no colo dos "seedlings" de numerosas espécies de Eucalyptus, julguei de interêsse investigar, com o mesmo objetivo, os gêneros brasileiros de Myrtaceae e aquêles que compõem as famílias da ordem Myrtiflorae.

Preliminarmente, coletei sementes de grande número de gêneros de Myrtaceae. Isto pôsto, coloquei-as em condições de germinar, tal como procedi para com as sementes das espécies de Eucalyptus. Foi durante a germinação das sementes de goiaba (variedades de polpa branca e vermelha) que notei o desprendimento de um opérculo, à semelhança do que se passa com os frutos pixídios e com as cápsulas dos musgos, no momento da deiscência.

Pelo que me foi dado comprovar, a deiscência opera-se no ato da germinação (Fig. 1), devido à pressão que a ponta da 
radícula exerce, ao crescer, contra a face interna e ligeiramente aconcheada do opérculo. Este, à guiza de rolha de garrafa que cede ante a pressão interna do gás, vai se soltando.

Comumente o opérculo permanece quer aderente à radícula, quer nos bordos do canal, onde se encontrava encaixado.

Os "seedlings" de Psidium Guayava L. exibem, por seu turno, o órgão cupuliforme, embora menos pronunciado que os revelados pelas espécies de Eucalyptus.

Em face da existência de um opérculo nas sementes de Psidium Guayava, órgão provàvelmente não assinalado ainda para a Botânica, elaborei a presente nota preliminar. Entrementes, continuo com as observaçöes em andamento, pois tenciono verificar se as espécies e gêneros de Myrtaceae, bem como as famílias que integram a ordem Myrtiflorae, possuem, também, o opérculo, cuja origem e estrutura pretendo estudar.

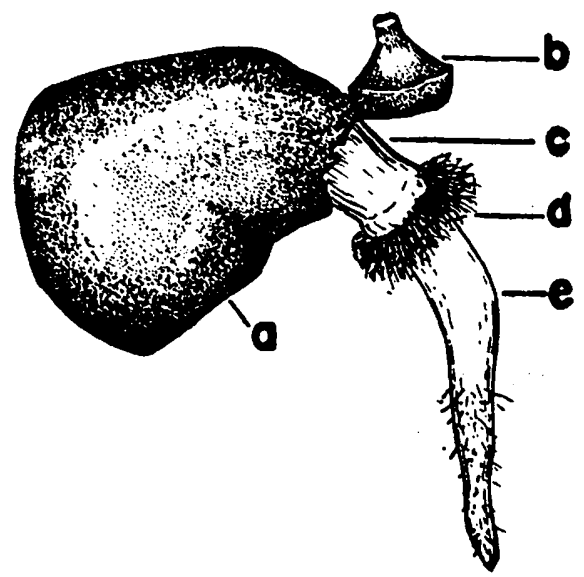

Fig.1 - Semente de Psidium Guagava (polpa branca) durante a germinação (Original). Aumento $10 \mathrm{x}$.

a - parte da semente (estojo córneo);

b - opérculo aderente ao bordo da abertura;

c - hipocótilo; d - órgão cupuliforme com pêlos absorventes; e - radícula. 